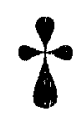

Die Redaktion gibt hiemit Nachricht von dem am 23. Juli 1903 erfolgten Tode des Herrn

\title{
EDUARD WEYR
}

Professor der Mathematik an der böhmischen technischen Hochschule in Prag.

Er gehörte zu den tätigsten und erfolgreichsten Mathematikern seiner Nation, insbesondere beklagt die Gesellschaft der tschechischen Mathematiker in Prag den Verlust eines ihrer hervorragendsten Mitglieder. Er gehörte auch zu den Mitarbeitern unserer Zeitschrift, welche von seinem im Jahre 1894 verstorbenen Bruder Emil Weyr mitbegründet wurde. 